\title{
INFLUÊNCIA DA PLUVIOSIDADE SOBRE A ABUNDÂNCIA E RIQUEZA DE MICROCRUSTÁCEOS (CRUSTACEA, CLADOCERA, CHYDORIDAE) EM UM RESERVATÓRIO DO SEMIÁRIDO BAIANO
}

\author{
Ferreira, G.R.S. ${ }^{1,}$; Oliveira, P.M. ${ }^{1}$ \& MITSUKA, P.M. ${ }^{1}$ \\ ${ }^{1}$ Universidade do Estado da Bahia (UNEB) - Campus VI, Grupo de Pesquisa Ecologia do Semiárido, \\ Laboratório de Ecologia Aquática. \\ *Autor correspondente: rene-tn@hotmail.com
}

\begin{abstract}
A família Chydoridae é composta por organismos de hábitos bentônicos, mas que também possuem certa capacidade natatória e podem estar associados a macrófitas. Além disso, é considerada a mais diversificada dentre os cladóceros, estando distribuída na maioria dos corpos d'água do Brasil. O presente trabalho teve como objetivo realizar levantamento da riqueza de espécies de Chydoridae no Tanque de Aroeiras (Caetité-Bahia), verificando possíveis influências dos índices pluviométricos sobre a abundância e riqueza da comunidade. Foram realizadas coletas no início do período chuvoso (novembro/2017) e no final (março/2018), em quatro estações na região marginal do reservatório. Em cada estação, foram filtrados 50 litros de água em uma rede de plâncton com espessura de $50 \mu \mathrm{m}$. O material foi acondicionado em frascos de vidro e fixado com formol $5 \%$. Em laboratório, os organismos foram triados em microscópio estereoscópio para posterior identificação em microscópio óptico, através de bibliografia específica. Os dados pluviométricos foram obtidos do Instituto Nacional de Meteorologia. Não houve variação significativa na riqueza, entretanto a abundância aumentou em mais de 100\%, concomitante a elevação da pluviosidade. Em novembro/2017, foram identificadas cinco espécies (Alona guttata, Chydorus nitidulus, Chydorus pubescens, Coronatella monocantha e Magnospina dentifera), com abundância total de 120 indivíduos. Já em março/2018, a riqueza foi de seis espécies (Chydorus eurynotus, C. nitidulus, C. pubescens, C. monacantha, Euryalona orientalis e Oxyurella longicaudis) e a abundância total de 500 indivíduos. A variação da abundância pode ter ocorrido porque até a data da primeira coleta não houve precipitação e no mês anterior os índices pluviométricos estiveram próximos a zero, por isso o reservatório ainda apresentava características limnológicas do período seco, como profundidades que variaram de 48 a 111 $\mathrm{cm}$ e ausência parcial ou total de macrófitas aquáticas nas estações amostradas. Ao final do período chuvoso, todas as estações possuíam bancos de macrófitas bem estabelecidos e desenvolvidos, com profundidades que variaram de 106 a $163 \mathrm{~cm}$, de modo que se verificou a variação espacial e temporal de espécies, bem como o aumento da riqueza e abundância da comunidade. Conclui-se, portanto, que a variação da pluviosidade com consequentes alterações nos níveis de profundidade dos reservatórios pode exercer influência sobre a riqueza e abundância da comunidade.
\end{abstract}

Palavras-chave: Chydoridae, influência, limnológicas, precipitação, semiárido. 